\title{
Utility of intraoperative neuromonitoring during percutaneous cement discoplasty
}

\section{Precisión del neuromonitoreo intraoperatorio durante la discoplastia percutánea con cemento \\ Precisão do neuromonitoramento intraoperatório durante discoplastia com cimento percutáneo}

\author{
Gaston Camino-Willhuber ${ }^{1,4}$, Mariana Bendersky ${ }^{2,3,5}$, Carolina Vilte ${ }^{3,6}$, Gonzalo Kido ${ }^{1,7}$, Matias Pereira-Duarte ${ }^{1,8}$, Martín \\ Estefan $^{1,9}$, Julio Bassani ${ }^{1,10}$, Matias Petracchi ${ }^{1,11}$, Marcelo Gruenberg ${ }^{1,12}$, Carlos Sola ${ }^{1,13}$.
}

En este estudio buscamos demostrar la utilidad de una herramienta (monitoreo) que utilizan los neurólogos para detectar alteraciones en los nervios a través de un estímulo, debido a que el paciente se encuentra dormido por la anestesia durante la cirugía, el monitoreo permite detectar si el cirujano esta próximo a un nervio a los fines de disminuir o evitar dañarlo.

\section{Conceptos clave}

Que se sabe sobre el tema?

La Discoplastia percutánea es un procedimiento relativamente nuevo, que consiste en rellenar con cemento el espacio discal intervertebral en discos con un avanzado desgaste y presencia de gas intradiscal, a los fines de estabilizar el segmento y así disminuir el dolor lumbar en pacientes ancianos con enfermedad degenerativa lumbar avanzada. Durante el procedimiento de inyección de cemento existe riesgo de dañar el nervio intervertebral, por lo que el monitoreo electrofisiológico durante la cirugía nos alertaría cuando estamos cerca de irritar un nervio.

\section{Que aporta este trabajo?}

Este es el primer trabajo que evalúa la utilidad del monitoreo electrofisiológico durante la Discoplastia para detectar posibles daños de los nervios intervertebrales durante el procedimiento.

1- Instituto de Ortopedia y Traumatología "Carlos E. Ottolenghi" Hospital Italiano de Buenos Aires, Ciudad de Buenos Aires, Argentina.

2- III Normal Anatomy Department, School of Medicine, University of Buenos Aires, Paraguay 2155, Buenos Aires, Argentina.

3- Intraoperative Monitoring, Pediatric Neurology Department, H, Potosi 4215, Buenos Aires, Hospital Italiano de Buenos Aires, Argentina.

4- E-mail de contacto: gaston.camino@hospitalitaliano.org.ar

5- E-mail de contacto: mariana.bendersky@hospitalitaliano.org.ar

6- E-mail de contacto: carolina.vilte@hospitalitaliano.org.ar

7- E-mail de contacto: gonzalo.kido@hospitalitaliano.org.ar

8- E-mail de contacto: matias.pereira@hospitalitaliano.org.ar

9- E-mail de contacto: drmartinestefan@gmail.com

10- E-mail de contacto: julio.bassani@hospitalitaliano.org.ar

11- E-mail de contacto: matias.petracchi@hospitalitaliano.org.ar

12- E-mail de contacto: marcelo.gruenberg@hospitalitaliano.org.ar

13- E-mail de contacto: carlos.sola@hospitalitaliano.org.ar

\section{Abstract:}

Introduction: Percutaneous cement discoplasty is a minimally invasive procedure to treat low back pain due to advanced degenerative disc disease in elderly patients. Complications of this procedure has been described such as infection, vertebral fracture, cement leakage and nerve injury. Intraoperative neuromonitoring is used to detect the latter. The objective of this study was to assess the usefulness of neuromonitoring during discoplasty to detect new neurological compromise. Methods: 100 consecutive patients were included in this retrospective study, ( 30 males and 70 females, mean age of $76.3 \pm$ 5.71 years) with mechanical low back pain who underwent percutaneous cement discoplasty. Results: Sensitivity to detect neurological injury was $82 \%$ (Cl 95\% 66-98), specificity was of $99 \%(\mathrm{Cl} 95 \% 98-100)$ with a positive predictive value of $0.95(\mathrm{Cl} 95 \%$ 85-100) and a negative predictive value of 0.97 (Cl 95\% 95-99). In 5 patients neurological compromise was not detected by neuromonitoring. Discussion: Our study showed high sensitivity and specificity of neuromonitoring to detect neurological irritation during percutaneous discoplasty. Intraoperative neuromonitoring resulted an effective assistance during this minimally invasive procedure.

Keywords: scoliosis; back pain; spinal diseases.

\section{Resumen:}

Introducción: La Discoplastia percutánea con cemento es un procedimiento mínimamente invasivo para tratar el dolor lumbar debido a la enfermedad degenerativa del disco avanzada en pacientes ancianos. Se han descrito complicaciones de este procedimiento como infección, fractura vertebral, fuga de cemento y lesión nerviosa. El neuromonitoreo intraoperatorio se utiliza para detectar este último. El objetivo de este estudio fue evaluar la utilidad del neuromonitoreo intraoperatorio durante la Discoplastia para detectar un nuevo compromiso neurológico. Materiales y Métodos: se incluyeron en este estudio retrospectivo 100 pacientes consecutivos (30 varones y 70 mujeres, edad media 76,3 $\pm 5,71$ años) con lumbalgia mecánica sometidos a Discoplastia percutánea con cemento. Resultados: La sensibilidad para detectar lesión neurológica fue del $82 \%$ (IC 95\% 66-98), la especificidad fue del 99\% (IC 95\% 98-100) con un valor predictivo positivo de 0,95 (IC 95\% 85-100) y un valor predictivo negativo. valor predictivo de 0,97 (IC 95\% 95-99). En 5 pacientes no se detectó compromiso neurológico mediante neuromonitoreo. Discusión: Nuestro estudio mostró una alta sensibilidad y especificidad del neuromonitoreo intraoperatorio para detectar irritación neurológica durante la discoplastia percutánea. El neuromonitoreo intraoperatorio resultó una ayuda eficaz durante este procedimiento mínimamente invasivo.

Palabras clave: escoliosis; dolor de espalda; enfermedades de la columna vertebral.

\section{Resumo:}

Introdução: A discoplastia percutânea com cimento é um procedimento minimamente invasivo para o tratamento da lombalgia por doença degenerativa discal avançada em pacientes idosos. As complicações desse procedimento foram descritas, como infecção, fratura vertebral, vazamento de cimento e lesão nervosa. $O$ neuromonitoramento intraoperatório é usado para detectar o último. O objetivo deste estudo foi avaliar a utilidade do neuromonitoramento durante a discoplastia para detectar novos comprometimentos neurológicos. Métodos: 100 pacientes consecutivos foram incluídos neste estudo retrospectivo, (30 homens e 70 mulheres, idade média de 76,3 $\pm 5,71$ anos) com lombalgia mecânica, submetidos à discoplastia percutânea com cimento. Resultados: A sensibilidade para detectar lesão neurológica foi de 82\% (IC 95\% 66-98), a especificidade foi de $99 \%$ (IC 95\% 98-100) com um valor preditivo positivo de 0,95 (IC 95\% 85-100) e negativo valor preditivo de 0,97 (IC 95\% 95-99). Em 5 pacientes, o comprometimento neurológico não foi detectado por neuromonitoramento. Discussão: Nosso estudo mostrou alta sensibilidade e especificidade do neuromonitoramento para detectar irritação neurológica durante a discoplastia percutânea. O neuromonitoramento intraoperatório resultou em uma assistência eficaz durante esse procedimento minimamente invasivo.

Palavras-chave: escoliose; dor nas costas; doenças da coluna vertebral.

DOI: http://dx.doi.org/10.31053/1853.0605.v78.n3.32619 


\section{INTRODUCTION}

Percutaneous cement discoplasty (PCD) has emerged as a minimally invasive surgical option to treat mechanical low back pain in elderly patients with advanced lumbar degeneration and intervertebral vacuum phenomenon ${ }^{(1-4)}$. This procedure consists of Polymethylmethacrylate (PMMA) injection through a cannulated needle into a partial or total intervertebral vacuum acting as a spacer and stabilizing the vertebral disc unit.

Complications associated with PCD have been reported $^{(5,6)}$, including cement leakage, adjacent vertebral fracture, infection, radicular injury secondary to cement leakage or during cannula positioning. Two techniques help to improve the accuracy and safety of percutaneous procedures like this, especially in deformity cases: The first one involves a good quality biplanar fluoroscopy, aiding in either planning the trajectory of the cannula or detecting a mispositioned one. The second approach involves intraoperative neuromonitoring (IONM), a combination of techniques with proven utility in spine surgery to decrease the risk of neurological injury, and above all in minimally invasive procedures in which direct visualization is limited ${ }^{(7-9)}$. In this kind of procedures, a tailor-made IONM is required, usually adapting techniques first developed for monitoring placement of lumbosacral screws. However, to our knowledge, its usefulness in PCD has not been previously evaluated.

The objective of this study is to assess the sensitivity and specificity of intraoperative neuromonitoring to detect neurological compromise in patients treated with PCD in our institution. We hypothesized that neuromonitoring had good sensitivity and specificity in detecting new neurological procedure-related events during percutaneous discoplasty.

\section{MATERIALS AND METHODS}

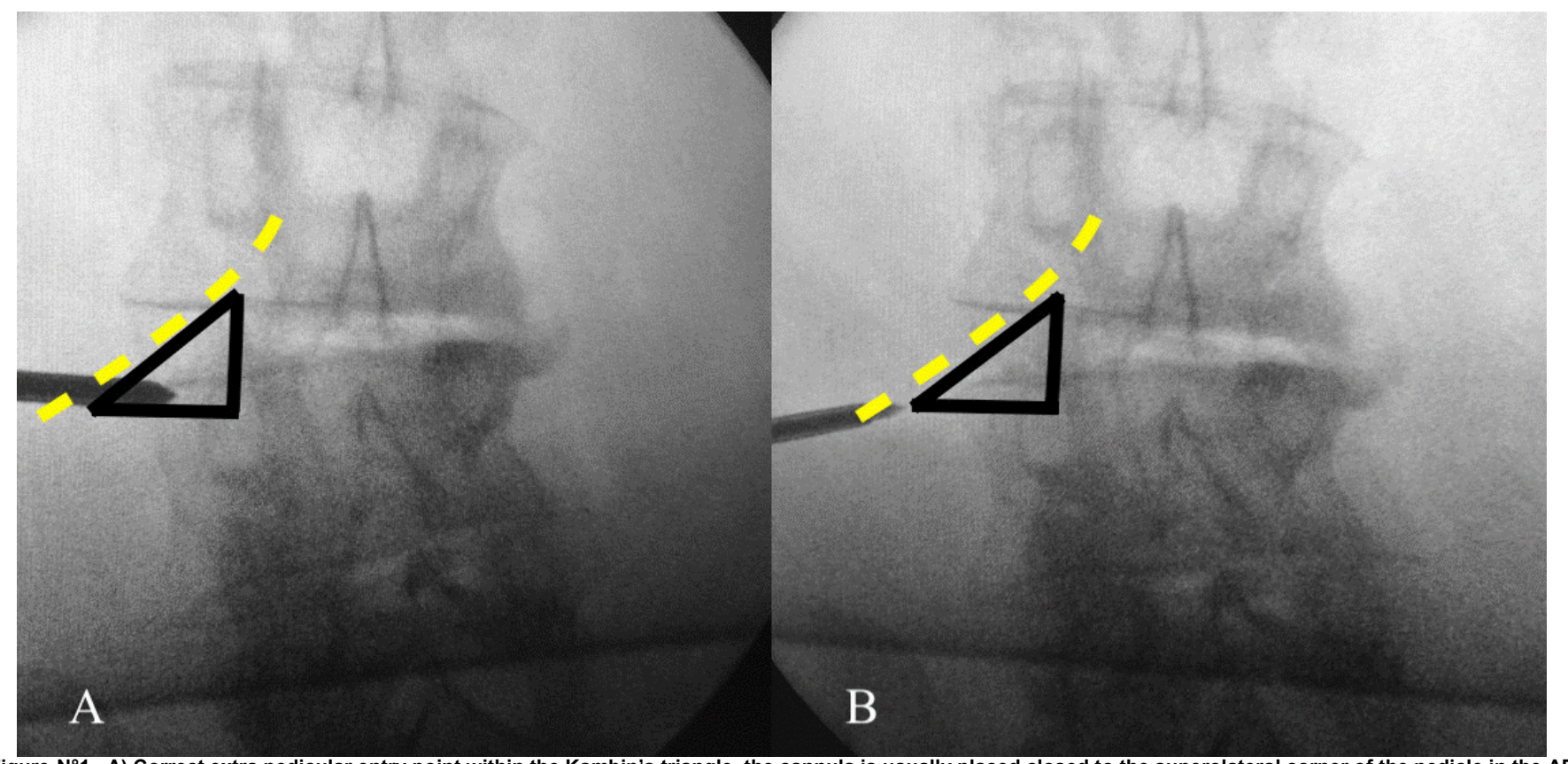

Figure $\mathrm{N}^{\circ}$ 1. A) Correct extra pedicular entry point within the Kambin's triangle, the cannula is usually placed closed to the superolateral corner of the pedicle in the AP view in order to avoid the exiting proximal nerve root (discontinued yellow line) B) Incorrect extra pedicular entry point outside the Kambin's triangle with higher risk of nerve injury due to nerve proximity. 


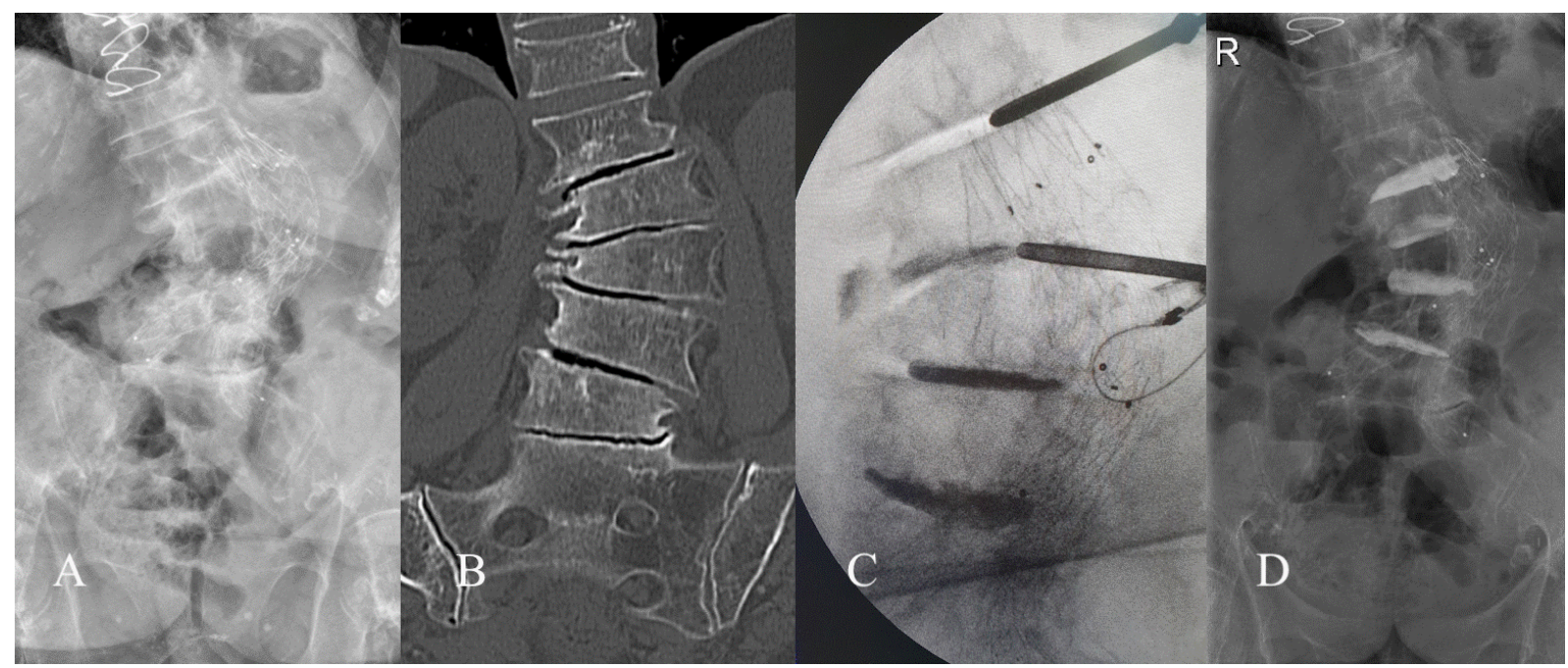

Figure $\mathrm{N}^{\circ}$. A-B) X-ray and CT AP views of a severe scoliotic case C) Cannula positioning guided by radioscopy and neuromonitoring is especially challenging in severe

deformity cases D) Postoperative AP x-ray of PCD

Intraoperative neuromonitoring

The three steps are guided by intraoperative neurophysiological monitoring. The anesthetic protocol is defined by the requirement for electromyography (EMG) and motor evoked potentials (MEP) monitoring, employing total intravenous anesthesia. Muscle relaxants are used only for intubation and then avoided for the remainder of the surgical procedure.

Small monopolar non insulated needle electrodes are placed in target muscles dependent upon the spinal region being operated. Additional recording electrodes are placed in the Abductor hallucis, for the train-of-4 stimulation over the tibialis nerve, to determine the level of muscle relaxants after positioning the patient and before the beginning of the procedure.

Reference and return electrodes are placed on the patient's upper thigh and near the surgical site, respectively.

All patients received somatosensory evoked potential (SSEP) and transcranial MEP monitoring, which is considered "standard of care" in our institution for these types of surgical procedures; nevertheless the tailored Intraoperative neuromonitoring (IONM) approach mostly refers to the following techniques: Free-run EMG is conducted during the whole procedure, employing multiple simultaneous channels of a NIM Eclipse $®$ neuromonitoring system (Medtronic), looking for spontaneous denervatory activity or complex repetitive discharges during the introduction of the cannula or the cement injection. Continuous stimulation through the Jamshidi needle is performed, employing a clamp stimulator, with a maximum intensity of $10 \mathrm{~mA}$, looking for a neural response indicating radicular proximity. It is assumed that a low response threshold indicates close proximity of the cannula to the nerve root.

During the injection of the cement, motor evoked potentials are performed; to monitor central motor pathway function and to detect unnoticed cement spills into the spinal canal.

\section{Definitions of neuromonitoring response during PCD:}

The stimulus intensity required to elicit a trace compound muscle action potential from a

given target muscle had to be below $10 \mathrm{~mA}$ (usually thresholds are below $5 \mathrm{~mA}$ ) to ensure that there is no diffusion of the stimulus to neighboring segments.

1) True positive: a positive response to free-run EMG or stimulation confirmed as a) there was a coincidence between the side and the exiting nerve root in the foramen in the extrapedicular access as well as the closest nerve to the pedicle in the pedicular access. (e.g.
Right L3 nerve root in right L3-L4 extrapedicular access or left S1 nerve root in left side pedicular S1 access); b) a new postoperative neurological symptom; c) a breach confirmed intraoperatively, and/or on postoperative CT scans

2) False positive: positive response to free-run EMG or stimulation in a radicular level not being intervened

3) True negative: no response to free-run EMG or stimulation confirmed as a correctly positioned cannula on radioscopy and absence of postoperatively neurological symptoms

4) False negative: no response to free-run EMG or stimulation but neurological findings post operatively such as new radicular pain related to the treated level without any other possible explanation.

\section{Statistical analysis}

Sensitivity, specificity, positive predictive values (PPVs), and negative predictive values (NPVs) were determined using standard Bayesian techniques. Data obtained from surgical records were processed with IBM SPSS Statistics Version 21.0 (IBM Corporation, Armonk, New York, USA).

\section{RESULTS}

A total of 137 patients (346 levels) were treated with PCD in our institution from December 2015 to December 2019. In 11 cases neuromonitoring was incomplete, in 6 cases neuromonitoring was not used for personal decision of one of the treating surgeons, 12 cases with severe lumbar stenosis and 8 cases with known neurological deficit were excluded from the analysis. After excluding all those cases, we obtained usable data from a total of 100 patients for the present study, (30 males and 70 females, mean age $[ \pm \mathrm{SD}]$ $76.3 \pm 5.71$ years). Electrophysiological testing was carried out on a total of 233 levels treated (218 extrapedicular levels between L1-L4 and 15 L5-Sacrum pedicular levels)

SSEP only showed intraoperative changes in one patient, whose results were also abnormal with the remaining techniques (EMG and MEP). 3 levels were true positive, 18 lead to a reposition of the cannula so finally the patient awoke with no new deficits (figure 3 ). In five patients IOM detected neural damage but despite modifying the surgical maneuver, the patients woke up with new neurological signs or symptoms. 

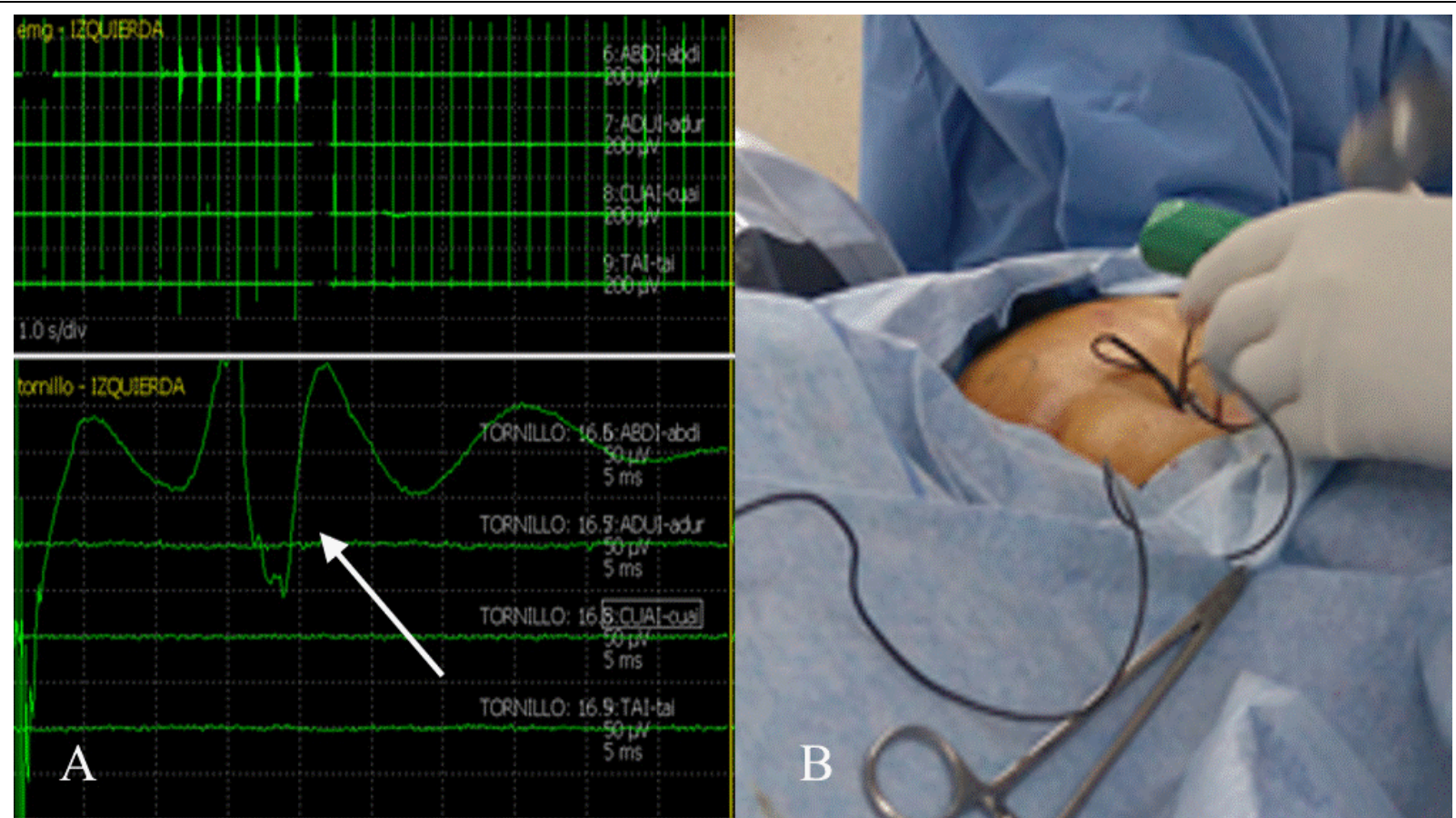

Figure $\mathrm{N}^{\circ}$ 3. A-B) Free-run EMG in 8 simultaneous channels, stimulation through the cannula yielded a neural response in one of the myotomes explored (see arrow) during cannula placement.

One level resulted in false positive, probably related to a technical issue. 205 levels yielded true negative results. In five patients, IONM failed to detect neural damage (false negative), 4 feminine/ one masculine, mean age $75.8 ; 3$ patients had radicular pain and 2 patients showed a new motor deficit, in all cases there was cement leakage into the in the homolateral side (figure 4). Two of these patients had poor basal responses, due to a preexistent polyneuropathy. Apart from the pre-existing pathology, no other variables were found, neither age nor sex nor the number of levels intervened, that correlate with these results. None of those patients had a preoperative electrodiagnostic evaluation, to evaluate possible distal axonal degeneration due to severe chronic radiculopathy.

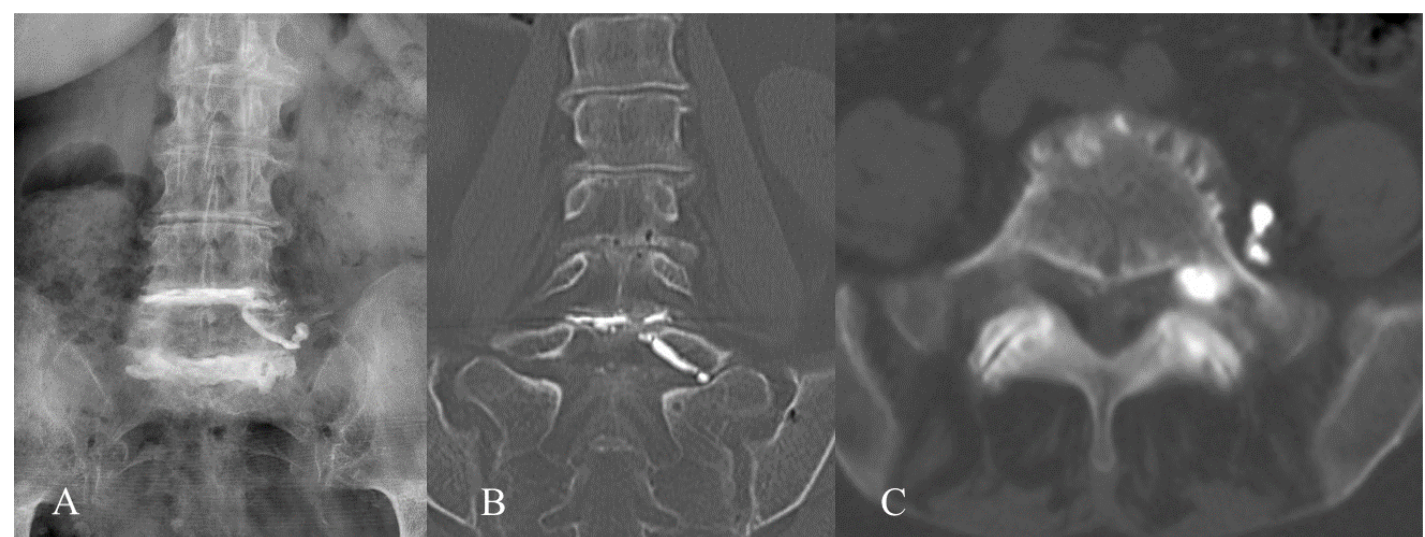

Figure $\mathrm{N}^{\circ}$ 4: 78 years old female treated with PCD at L4-L5 and L5-Sacrum levels, cement leakage at L5-Sacrum foramen is observed, not detected by IONM (False negative), the patient underwent decompression surgery due to radicular pain.

Given those results, sensitivity was $82 \%$ (Cl 95\% 66-98), specificity was of $99 \%$ (Cl 95\%98-100) with a positive predictive value of 0.95 (Cl 95\% 85-100) and a negative predictive value of 0.97 (CI 95\% 9599). Receiver operative characteristics (ROC) curve (figure 5) analysis from these results showed and area under the curve of 0.85 . 


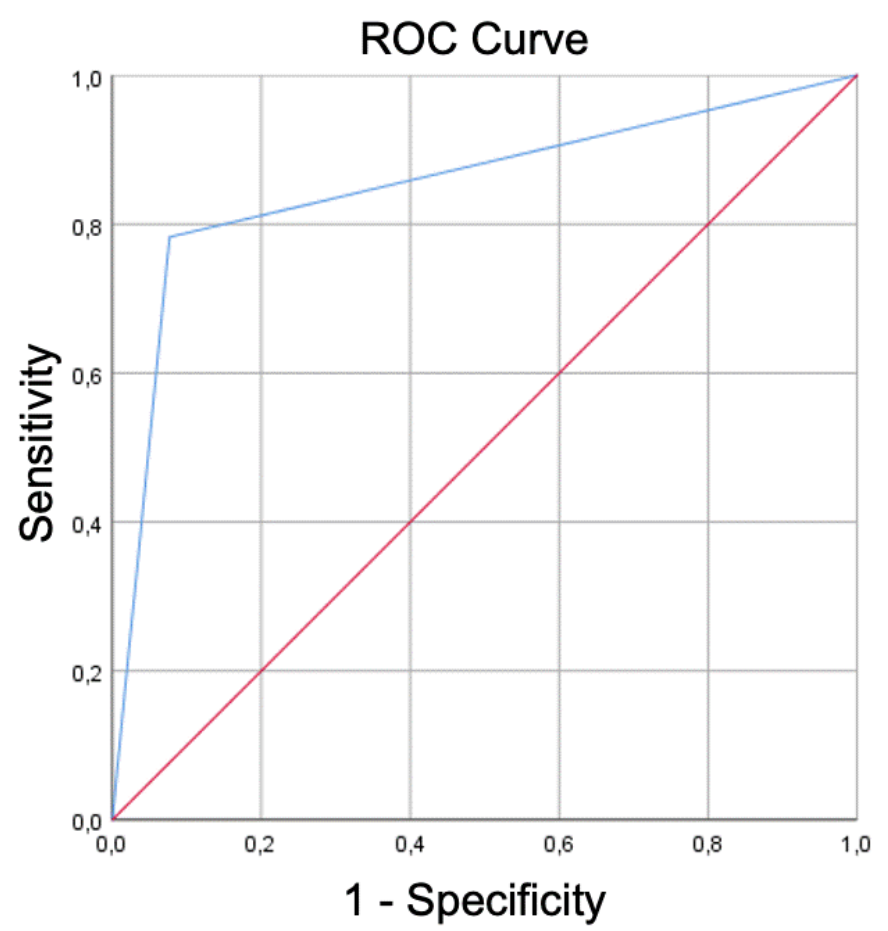

Figure $N^{\circ} 5$ : ROC curve with and area under the curve (AUC) or 0.85 showing good test utility.

\section{DISCUSSION}

According to our study, neuromonitoring showed a high sensitivity $(82 \%)$ and specificity $(99 \%)$ in detecting new-radicular stimulation when performing PCD. To avoid neural complications associated with this approach, as in most percutaneous procedures, it is recommended to add neurophysiological monitoring with free-run and triggered EMG and transcranial motor evoked potentials. Freerun EMG registers real-time muscle activity during the whole procedure. Mechanical stimulation of a nerve root leads to complex repetitive discharges in the EMG. Discrete threshold, triggered EMG provides real-time feedback of the proximity of the roots, as measured by the threshold required to depolarize them to elicit a response. Worth mentioning that chronically compressed nerve roots may have a higher stimulation threshold than uncompressed ones. A commonly made incorrect assumption is that neurophysiological abnormal findings are not related to any factor other than the presence of disease. We know that other factors such as age, previous neuropathy or technical issues such as morbid obesity can influence those findings. Moreover, given the advanced age of the patients undergoing this technique, and the fact that they have long-standing radiculopathies with probable secondary distal axonal degeneration, or comorbidities (e.g., diabetes), it would be advisable to perform an EMG with nerve conduction studies prior to the procedure in order to choose patients for whom the IONM will be worthwhile. For example, in patients with axonal polyneuropathies, the IONM is unlikely to detect any change in responses.

Regarding the role of neuromonitoring in preventing neurological injury during spine surgery the literature is ambiguous, on one hand, some studies suggest no benefit ${ }^{(13,14)}$, while other studies supports evidence of it use ${ }^{(7,15-17)}$, most of these studies also estate the need of improvement in protocols on how to manage intraoperative alerts $^{(18)}$. To our knowledge, this is the first study that analyses the utility of neuromonitoring during percutaneous discoplasty. In fact, neuromonitoring in PCD has only been mentioned in two previous studies from the authors ${ }^{(4,5)}$, with no mention in other studies ${ }^{(2,6)}$. Recently, Lazary ${ }^{(19)}$ argued about the use of neuromonitoring during PCD as they did not experience any nerve root injury during PCD in their case series ${ }^{(1,6)}$, contrary to our series, in which 5 from 100 patients suffered from nerve injury.

Another reason to consider neuromonitoring during PCD is the variation of the kambin's triangle anatomy described in the literature ${ }^{(10-23)}$, variation of the nerve root ganglion position described in cadaveric studies plays an important role as can be associated with increased nerve root injury in this working access used in minimally invasive surgery, ranging between 2 and $9 \%$ according to some studies ${ }^{(24,25)}$. The presence of deformity (as seen in figure 2) also make this access more challenging ${ }^{(26)}$. Even less frequent, nerve root anomalies should also be considered when performing procedures through the kambin's triangle ${ }^{(27,28)}$. Those variations may support the use of neuromonitoring to prevent nerve root injury.

\section{Limitations}

Our study has some limitations, first, we retrospectively reviewed a consecutive case series, therefore, factors that could influence nerve response in neuromonitoring such as peripheral neuropathy ${ }^{(29)}$, Wallerian degeneration or medication were not completely analyzed in our study, even though we excluded patients with well recorded neurological deficits, however, due to the retrospective nature of this study there might be a possibility that some patients with undiagnosed neuropathy were included. On the other hand, neuromonitoring was performed in all cases before, during and after the procedure and cases with neurological deficit were properly recorded. Another limitation is variability of the treating surgeons, in this study three surgeons from the same working group and institution performed the procedures, even though this variation can affect the results, all treating surgeons perform the technique in a similar fashion based on the step-by step technique developed by the authors ${ }^{(4)}$, in addition, the neuromonitoring was performed by the same neurologist (MB), this factor can be considered as a strength.

As we previously mentioned, this is the first study that analyzed the utility of neuromonitoring in PCD. More studies, with longer sample size and prospective analysis are required to assess the real benefit of PCD as a treatment option in elderly population, nevertheless, our results can be helpful to improve the technique and decrease the risk of neurological injury during this minimally invasive procedure.

\section{CONCLUSION}

Our study showed high sensitivity and specificity of neuromonitoring to detect neurological irritation when performing percutaneous cement discoplasty. Intraoperative neuromonitoring resulted an effective assistance during this minimally invasive procedure. 


\section{Limitaciones de responsabilidad:}

La responsabilidad de este trabajo es exclusivamente de los autores.

\section{Conflicto de interés:}

Ninguno

\section{Fuentes de apoyo:}

La presente investigación no contó con fuentes de financiación.

\section{Originalidad:}

Este artículo es original y no ha sido enviado para su publicación a otro medio de difusión científica en forma completa ni parcialmente.

\section{Cesión de derechos:}

Los participantes de este trabajo ceden el derecho de autor a la Universidad Nacional de Córdoba para publicar en la RFCM y realizar las traducciones necesarias.

\section{REFERENCES}

1. Varga PP, Jakab G, Bors IB, Lazary A, Szövérfi Z. Erfahrungen mit PMMA-Zement als intervertebraler Stand-alonePlatzhalter. Perkutane Zement-Diskoplastie bei Vakuumphänomen der lumbalen Bandscheiben [Experiences with PMMA cement as a stand-alone intervertebral spacer. Percutaneous cement discoplasty in the case of vacuum phenomenon within lumbar intervertebral discs]. Orthopade. 2015 Feb;44(2):124-31. German. doi: 10.1007/s00132-015-3092-1.

2. Yamada K, Nakamae $T$, Shimbo $T$, Kanazawa $T$, Okuda $T$, Takata H, Hashimoto T, Hiramatsu T, Tanaka N, Olmarker K, Fujimoto Y. Targeted Therapy for Low Back Pain in Elderly Degenerative Lumbar Scoliosis: A Cohort Study. Spine (Phila Pa 1976). $2016 \quad$ May;41(10):872-9. doi: 10.1097/BRS.0000000000001524.

3. Yamada K, Nakamae T, Nakanishi K, Kamei N, Hiramatsu $T$, Okuda T, Hashimoto $T$, Ujigo S, Morisako T, Tsuchikawa $Y$, Maruyama T, Fukui H, Adachi N, Shimbo T, Olmarker K, Fujimoto Y. Long-term outcome of targeted therapy for low back pain in elderly degenerative lumbar scoliosis. Eur Spine J. 2021 Jul;30(7):20202032. doi: 10.1007/s00586-021-06805-4.

4. Sola C, Camino Willhuber G, Kido G, Pereira Duarte M, Bendersky M, Mereles M, Petracchi M, Gruenberg M. Percutaneous cement discoplasty for the treatment of advanced degenerative disk disease in elderly patients. Eur Spine J. 2021 Aug;30(8):2200-2208. doi: 10.1007/s00586-018-5547-7.

5. Camino Willhuber G, Kido G, Pereira Duarte M, Estefan M, Bendersky M, Bassani J, Petracchi M, Gruenberg M, Sola C. Percutaneous Cement Discoplasty for the Treatment of Advanced Degenerative Disc Conditions: A Case Series Analysis. Global Spine J. 2020 Sep;10(6):729-734. doi: 10.1177/2192568219873885.

6. Kiss L, Varga PP, Szoverfi Z, Jakab G, Eltes PE, Lazary A. Indirect foraminal decompression and improvement in the lumbar alignment after percutaneous cement discoplasty. Eur Spine J. 2019 Jun;28(6):1441-1447. doi: 10.1007/s00586-019-05966-7.

7. Fehlings MG, Brodke DS, Norvell DC, Dettori JR. The evidence for intraoperative neurophysiological monitoring in spine surgery: does it make a difference? Spine (Phila Pa 1976). $2010 \mathrm{Apr}$ 20;35(9 Suppl):S37-46. doi: 10.1097/BRS.0b013e3181d8338e.

8. Tamkus AA, Rice KS, McCaffrey MT. Perils of intraoperative neurophysiological monitoring: analysis of "false-negative" results in spine surgeries. Spine J. 2018 Feb;18(2):276-284. doi: 10.1016/j.spinee.2017.07.005.

9. Lall RR, Lall RR, Hauptman JS, Munoz C, Cybulski GR, Koski $T$, Ganju A, Fessler RG, Smith ZA. Intraoperative neurophysiological monitoring in spine surgery: indications, efficacy, and role of the preoperative checklist. Neurosurg Focus. 2012 Nov;33(5):E10. doi: 10.3171/2012.9.FOCUS12235.

10. Camino Willhuber G, Bendersky M, De Cicco FL, Kido G, Duarte MP, Estefan M, Petracchi M, Gruenberg M, Sola C. Development of a New Therapy-Oriented Classification of Intervertebral Vacuum Phenomenon With Evaluation of Intra- and Interobserver Reliabilities. Global Spine J. 2021 May;11(4):480-487. doi: 10.1177/2192568220913006.

11. Schizas C, Theumann N, Burn A, Tansey R, Wardlaw $D$, Smith FW, Kulik G. Qualitative grading of severity of lumbar spinal stenosis based on the morphology of the dural sac on magnetic resonance images. Spine (Phila Pa 1976). 2010 Oct 1;35(21):191924. doi: 10.1097/BRS.0b013e3181d359bd.

12. Kambin $P$, Sampson S. Posterolateral percutaneous suction-excision of herniated lumbar intervertebral discs. Report of interim results. Clin Orthop Relat Res. 1986 Jun;(207):37-43.

13. Daniel JW, Botelho RV, Milano JB, Dantas FR, Onishi FJ, Neto ER, Bertolini EF, Borgheresi MAD, Joaquim AF. Intraoperative Neurophysiological Monitoring in Spine Surgery: A Systematic Review and Meta-Analysis. Spine (Phila Pa 1976). 2018 Aug;43(16):1154-1160. doi: 10.1097/BRS.0000000000002575.

14. Garces J, Berry JF, Valle-Giler EP, Sulaiman WA. Intraoperative neurophysiological monitoring for minimally invasive 1- and 2-level transforaminal lumbar interbody fusion: does it improve patient outcome? Ochsner J. 2014 Spring;14(1):57-61.

15. Scibilia A, Raffa G, Rizzo V, Quartarone A, Visocchi M, Germanò A, Tomasello F. Intraoperative Neurophysiological Monitoring in Spine Surgery: A Significant Tool for Neuronal Protection and Functional Restoration. Acta Neurochir Suppl. 2017;124:263-270. doi: 10.1007/978-3-319-39546-3_38.

16. Sutter M, Eggspuehler A, Jeszenszky D, Kleinstueck F, Fekete TF, Haschtmann D, Porchet F, Dvorak J. The impact and value of uni- and multimodal intraoperative neurophysiological monitoring (IONM) on neurological complications during spine surgery: a prospective study of 2728 patients. Eur Spine J. 2019 Mar;28(3):599-610. doi: 10.1007/s00586-018-5861-0.

17. Kaliya-Perumal AK, Charng JR, Niu CC, Tsai TT, Lai PL, Chen $\mathrm{LH}$, Chen WJ. Intraoperative electromyographic monitoring to optimize safe lumbar pedicle screw placement - a retrospective analysis. BMC Musculoskelet Disord. 2017 May 30;18(1):229. doi: 10.1186/s12891-017-1594-1

18. Charalampidis A, Jiang F, Wilson JRF, Badhiwala JH, Brodke DS, Fehlings MG. The Use of Intraoperative Neurophysiological Monitoring in Spine Surgery. Global Spine J. 2020 Jan;10(1 Suppl):104S-114S. doi: 10.1177/2192568219859314.

19. Lazary A. Expert's Comment concerning Grand Rounds Case entitled "Percutaneous cement discoplasty for the treatment of advanced degenerative disk disease in elderly patients" : (C. Sola, et al., Eur Spine J; 2018: DOI 10.1007/s00586-018-5547-7). Eur Spine J. 2021 Aug;30(8):2209-2210. doi: 10.1007/s00586-02006568-4.

20. Ozer AF, Suzer T, Can H, Falsafi M, Aydin M, Sasani M, Oktenoglu T. Anatomic Assessment of Variations in Kambin's Triangle: A Surgical and Cadaver Study. World Neurosurg. 2017 Apr;100:498-503. doi: 10.1016/j.wneu.2017.01.057.

21. Zhang $L$, Yang J, Hai $Y$, Yin $P$, Ding $Y, X u C$, Gao $H$. Relationship of the Exiting Nerve Root and Superior Articular Process in Kambin's Triangle: Assessment of Lumbar Anatomy Using Cadavers and Computed Tomography Imaging. World Neurosurg. $2020 \quad$ May;137:e336-e342. doi: 10.1016/j.wneu.2020.01.195. 
22. Hoshide R, Feldman E, Taylor W. Cadaveric Analysis of the Kambin's Triangle. Cureus. 2016 Feb 2;8(2):e475. doi: 10.7759/cureus. 475

23. Fanous AA, Tumialán LM, Wang MY. Kambin's triangle: definition and new classification schema. J Neurosurg Spine. 2019 Nov 29:1-9. doi: 10.3171/2019.8.SPINE181475. Epub ahead of print.

24. Ahn Y, Lee SH, Lee JH, Kim JU, Liu WC. Transforaminal percutaneous endoscopic lumbar discectomy for upper lumbar disc herniation: clinical outcome, prognostic factors, and technical consideration. Acta Neurochir (Wien). 2009 Mar;151(3):199-206. doi: 10.1007/s00701-009-0204-x. Epub 2009 Feb 20. Erratum in: Acta Neurochir (Wien). 2009 Nov;151(11):1561.

25. Yeung AT, Tsou PM. Posterolateral endoscopic excision for lumbar disc herniation: Surgical technique, outcome, and complications in 307 consecutive cases. Spine (Phila Pa 1976). 2002 Apr 1;27(7):722-31. doi: 10.1097/00007632-20020401000009.

26. Lertudomphonwanit $T$, Keorochana G, Kraiwattanapong $C$, Chanplakorn P, Leelapattana $P$, Wajanavisit W. Anatomic Considerations of Intervertebral Disc Perspective in Lumbar Posterolateral Approach via Kambin's Triangle: Cadaveric Study. Asian Spine J. 2016 Oct;10(5):821-827. doi: 10.4184/asj.2016.10.5.821.

27. Schmidt CK, Rustagi T, Alonso F, Loukas M, Chapman $J R$, Oskouian RJ, Tubbs RS. Nerve root anomalies: making sense of a complicated literature. Childs Nerv Syst. 2017 Aug;33(8):12611273. doi: 10.1007/s00381-017-3457-3.

28. Can H, Kircelli A, Kavadar G, Civelek E, Cansever $T$, Aydoseli A, Onal MB, Yilmaz C. Lumbosacral Conjoined Root Anomaly: Anatomical Considerations of Exiting Angles and Root Thickness. Turk Neurosurg. 2017;27(4):617-622. doi: 10.5137/10195149.JTN.16490-15.1.

29. Rivner MH. Statistical errors and their effect on electrodiagnostic medicine. Muscle Nerve. 1994 Jul;17(7):811-4. doi: 10.1002/mus. 880170718. 